\title{
PREFACE
}

\section{COSMOGENIC ISOTOPE PALEOGEOPHYSICS - PALEOASTROPHYSICS AND NATURAL VARIATION OF COSMOGENIC ISOTOPES}

In order to confirm the radiocarbon half-life of $5568 \pm 30$ years, based upon then available measurements, Willard Libby (1955) produced the first calibration of the radiocarbon time scale, using samples of known age dating back to $5000 \mathrm{BC}$. He concluded that this half-life was valid and that the ${ }^{14} \mathrm{C} /{ }^{12} \mathrm{C}$ ratio of atmospheric $\mathrm{CO}_{2}$ was sufficiently constant to permit accurate dating of paleoevents. A few years later, this assumption was brought into question by Hessel de Vries' (1958) discovery of fluctuations of the ${ }^{14} \mathrm{C} /{ }^{12} \mathrm{C}$ atmospheric ratio of up to $2 \%$ during the Little Ice Age, involving an inaccuracy of the time scale of 160 years. Shortly afterward, workers in the United States demonstrated that the de Vries effect 'wiggles' were superimposed upon longer-term trends (Ralph \& Stuckenrath 1960; Suess 1961; Damon, Long \& Sigalove 1963). At the International Radiocarbon Conference in Cambridge (Godwin 1962a), accurate measurements were available to designate a new half-life $(5730 \pm 40$ years) (Godwin 1962b) for geophysicalgeochemical purposes, and it was then apparent to all attendants that systematic calibration of the radiocarbon time scale was essential (see Damon 1987, for a history of the calibration of the radiocarbon time scale).

Willis, Tauber and Münnich (1960) showed that the de Vries-effect secular variations extended back over the past 1300 years, and appeared to be cyclical, with a period of about 200 years. Shortly thereafter, Stuiver $(1961,1965)$ demonstrated that the de Vries effect was the result of modulation of radiocarbon production by solar activity. At an earlier date, Suess (1955) had demonstrated a rapid decrease in atmospheric ${ }^{14} \mathrm{C}$ activity resulting from injection of ${ }^{14} \mathrm{C}$-depleted $\mathrm{CO}_{2}$ into the atmosphere from combustion of fossil fuels (the Suess effect). It then became apparent that there were generally three categories of possible causes for secular variation of atmospheric $\left.{ }^{14} \mathrm{C}: 1\right)$ variations in the global rate of ${ }^{14} \mathrm{C}$ production; 2) variation in the rate of exchange between geochemical reservoirs accompanied by changes in the inventory of the various geochemical reservoirs of $\mathrm{CO}_{2}$; and 3) variations in the total $\mathrm{C}$ content of all reservoirs that contain significant amounts of ${ }^{14} \mathrm{C}$ (atmosphere, biosphere, hydrosphere and sediments).

By the time of the 12th Nobel Symposium on "Radiocarbon Variations and Absolute Chronology" held in Uppsala during the summer of 1969, the most significant causes of secular variation of atmospheric ${ }^{14} \mathrm{C}$ had been identified (Olsson 1970): changes in the Earth's dipole moment, changes in solar activity and changes in climate. Attention had also been drawn to possible changes in the galactic cosmic-ray flux entering the solar system, such as those caused by supernovae explosions (Konstantinov \& Kocharov 1965; Lingenfelter \& Ramaty 1970) or possible intrusion of antimatter into the solar system (Libby 1965). Thus, the 12th Nobel Symposium was a 'watershed' dividing the earlier exploratory research and the subsequent developments in ${ }^{14} \mathrm{C}$ research. The results of 1200 intermediate-precision ${ }^{14} \mathrm{C}$ measurements on tree rings provided the basis for subsequent paleogeophysical-paleoastrophysical studies (Damon et al. 1980), until high-precision calibrated dates back through the 8 th millennium BC were published following the 12th International Radiocarbon Conference held in Trondheim in June 1985 (Stuiver \& Kra 1986). A new set of data will shortly become available with the publication of the new Calibration Issue 1993 (Stuiver, Long \& Kra 1993).

Most early research was based on decadal or bidecadal tree-ring samples. The study of solar variations additionally requires annual data to examine the solar activity in both its harmonic 
and chaotic phases. It is important to extend available data beyond the last 10,000 years and into the last glacial age. The use of other isotopes in other natural archives, such as ${ }^{10} \mathrm{Be}$ in polar ice, is an essential adjunct to complement ${ }^{14} \mathrm{C}$ and, more importantly, to extend our paleogeophysicalpaleoastrophysical work back over hundreds of thousands and even millions of years. New instrumental concepts are evolving (Pavlov, Kogan \& Gladkov 1992), as well as a new understanding of solar physics (Nesme-Ribes \& Mangeney 1992).

It is important to recall that instrumental measurements of geophysical fields and astrophysical phenomena extend back only a few centuries. The use of cosmogenic isotopes opens a window into the much more distant past. The diligent reader of this issue will be rewarded with an overview of the advances and future directions of a relatively new field.

I wish to thank my colleague, Grant E. Kocharov, for co-chairing this Paleoastrophysics Workshop, and for invaluable help in editing the manuscripts.

Paul E. Damon

\section{REFERENCES}

Cowan, C., Atluri, C. R. and Libby, W. F. 1965 Possible anti-matter content of the tunguska meteor of 1908. Nature 206: 861-865.

Damon, P. E. 1987 The history of the calibration of radiocarbon dates by dendrochronology. In Aurenche, O., Evin, J. and Hourst, F., eds., Relative Chronologies and Absolute Chronology 16,000-4,000 BP. BAR International Series 379: 61-104.

Damon, P. E., Lerman, J. C., Long, A., Bannister, B., Klein, J. and Linick, T. W. 1980 Report on the workshop on calibration of the radiocarbon time scale. In Stuiver, M. and Kra, R. S., eds., Proceedings of the 10 th International ${ }^{14} \mathrm{C}$ Conference. Radiocarbon 22(3): 947-949.

Damon, P. E., Long, A. and Sigalove, J. J. 1963 Arizona radiocarbon dates IV. Radiocarbon 5: 283-301.

de Vries, H. 1958 Variation in concentration of radiocarbon with time and location on earth. Koninklijke Nederlandse Akademie van Wetenschappen. Proceedings Series B 61: 94-102.

Godwin, H. 1962a Radiocarbon dating. Nature 195: 984.

1962b Half-life of radiocarbon. Nature 195: 984.

Konstantinov, B. P. and Kocharov, G. E. 1965 Astrophysical phenomena and radiocarbon. Doklady Akademii Nauk SSSR 165: 63-64.

Libby, W. F. 1955 Radiocarbon Dating. Second Edition. Chicago, University of Chicago Press: 175 p.

Lingenfelter, R. E. and Ramaty, R. 1970 Astrophysical and geophysical variations in ${ }^{14} \mathrm{C}$ production. In Olsson, I., ed., Radiocarbon Variations and Absolute Chronology. Proceedings of the 12th Nobel Symposium. New York, John Wiley \& Sons: 513-537.

Nesme-Ribes, E. and Mangeney, A. 1992 On a plausible physical mechanism linking the Maunder Minimum to the Little Ice Age. Radiocarbon, this issue.

Olsson, I., ed. 1970 Radiocarbon Variations and Absolute Chronology. Proceedings of the 12th Nobel Symposium. New York, John Wiley \& Sons: 652 p.

Pavlov, A. K., Kogan, V. T. and Gladkov, G. Y. 1992 A tandem mass-spectrometric method of cosmogenic isotope analysis. Radiocarbon, this issue.

Ralph, E. K. and Stuckenrath, R. 1960 Carbon-14 measurements of known age samples. Nature 188 185-187.

Stuiver, M. 1961 Variations in radiocarbon concentration and sunspot activity. Journal of Geophysical Research 66: 273-276.

1965 Carbon-14 content of 18 th- and 19 th-century wood, variations correlated with sunspot activity. Science 149: 533-535.

Stuiver, M. and Kra, R. S., eds. 1986 Calibration Issue. Proceedings of the 12th International Radiocarbon conference. Radiocarbon 28(2B): 1030 p.

Stuiver, M., Long, A. and Kra, R. S., eds. 1993 Calibration Issue 1993. Radiocarbon 35(1), in press.

Suess, H. E. 1955 Radiocarbon concentration in modern wood. Science 122: 415-417.

1961 Secular variations in the concentration of atmospheric radiocarbon. In Proceedings of a Conference on Problems Related to Interplanetary Matter. NAS-NRC Publication 845: 90-95.

Willis, E. H., Tauber, H. and Münnich, K. O. 1960 Variations in the atmospheric radiocarbon concentration over the past 1300 years. Radiocarbon 3: 1-4. 